\title{
Determination of trophic situation of Sarimsakli Dam Lake (Kayseri-Turkey)
}

\author{
Didem Aydin ${ }^{1}$ and Seyhan Ahiska ${ }^{2 *}$ \\ ${ }^{1}$ Erciyes University, Faculty of Arts and Science Department of Biology, 38039 Kayseri/ Turkey. \\ ${ }^{2}$ Ankara University, Faculty of Science Department of Biology, 06100 Ankara / Turkey
}

Accepted 12 October, 2009

\begin{abstract}
In this study, water samples were collected from four different stations in Sarımsaklı Dam Lake from May 2001 to June 2002 monthly to determine the trophic situation of lake. Additionally, physical parameters of water such as temperature, dissolved oxygen, electrical conductivity (EC), pH, light permeability were measured in the field and status of surface active substance, sulphur, nitrite, nitrate, total nitrogen, phosphate, total phosphate, oxygen saturation were analysed in Environment Ministry Reference Laboratory. Zooplankton samples were collected with a plankton net mesh size of $55 \mu \mathrm{m}$ horizontally and vertically and they were fixed with $4 \%$ formaldehyde. The results of the light permeability, basic water quality parameters and dominant zooplankton species indicated that the lake studied was eutrophic. Furthermore, biotic index confirmed this result. The Lake examined in study area was partly polluted with different sources, because the study area is liable to human activities. If the pollution is not prevented, it may endanger the lives of living organisms here in future. Knowledge on the trophic situation of Sarımsaklı Dam Lake is not well established; so all of the zooplankton species determined are new records.
\end{abstract}

Key words: Sarımsaklı Dam Lake, trophic status, water quality, zooplankton.

\section{INTRODUCTION}

Sarımsaklı Dam, which is located at $32 \mathrm{~km}$ away from Kayseri city centre, is founded on Sarımsaklı Stream in 1968 for the purpose of irrigation (Figure 1). The surface area of the dam lake is $2.44 \mathrm{~km}^{2}$. Fish species of Common Carp, Silverside and Zander were released to the dam lake. Agriculture and animal husbandry are common human practices around the dam lake. There is also a public picnic site around the lake.

\section{MATERIALS AND METHODS}

Study material was collected monthly between May 2001 and June 2002. Four stations were selected to characterize the whole lake area. Lots of streams ended to the lake area. There are also reedy areas around the lake. The management of Sarımsaklı Dam Lake has been handed over to an irrigation unity by General Directorate of State Hydraulic Works (DSI). Therefore, especially during the summertime, the water area of the lake decreased and in some

*Corresponding author. E -mail: ahiska@sicence.ankara.edu.tr. Fax: +903122232395 . months third and fourth stations were disappeared. The stations, however, reappeared with increasing rainfall and decreasing temperature.

From each station, water samples of $1 \mathrm{Lt}$ were taken for physical and chemical analyses of lake water. Water $\mathrm{pH}$ (WTW portable $\mathrm{pH}$ meter), dissolved oxygen (YSI 51 oxygen meter) and conductivity (WTW conductometer) were measured during the sampling process. Water temperature was determined with thermometry of $\mathrm{pH}$ meter

Light permeability was also measured during the sampling process with a $20 \mathrm{~cm}$ diameter Secchi disc. Water depth was determined with sounding method. The rest of the variables of water quality, which are chemical oxygen demand (COD), surfactant, sulphur, nitrate, nitrite, total nitrogen, phosphate, suspended solid matter and oxygen saturation, were determined at Reference Laboratory of Ministry of Environment of Turkey.

Hensen type plankton net with a mouth diameter of $25 \mathrm{~cm}$ and mesh size of $55 \mu \mathrm{m}$ (Hydro-Bios Kiel) was used to collect zooplankton samples.

Zooplankton samples were collected by both vertical and horizontal hauls in each station. In vertical hauls, according to the depth of the stations, samples were taken from various depths. Plankton samples were placed to $100 \mathrm{ml}$ plastic bottles and then $4 \%$ formaldehyde solution were also added. Taxonomic identification of the species was done according to Ward and Whipple, (1945), Edmondson (1959), Needham (1962), Dussart (1967), 

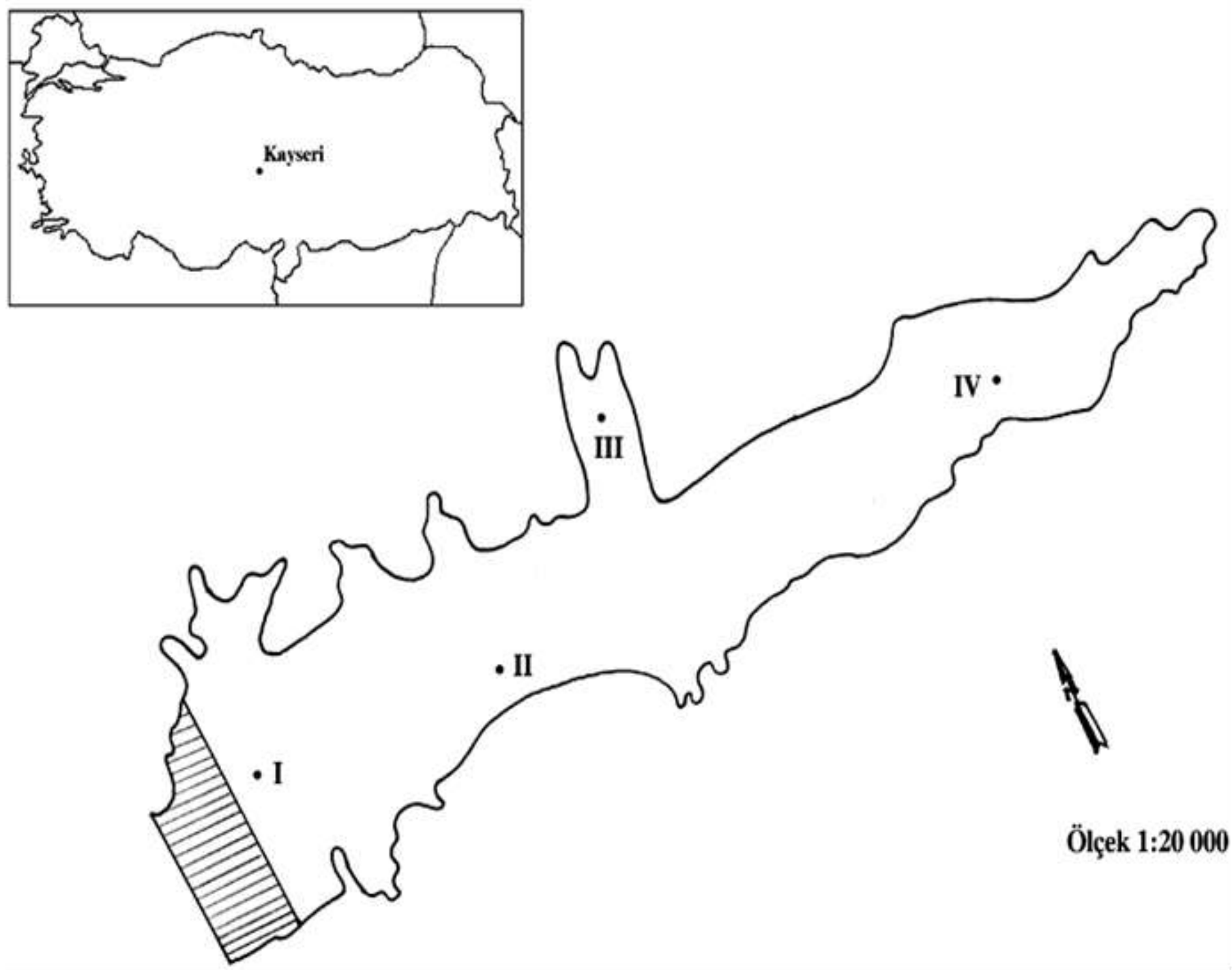

Figure 1. Map of study area and location of sampling station.

Kolisko (1974), Koste (1978) and Harding and Smith (1974).

\section{RESULTS AND DISCUSSION}

Maximum depth of the lake was measured as $20 \mathrm{~m}$ in May 2001. Third and fourth stations dried up in August, September and October 2001 due to water deficit. However, an increase in water level was observed after April 2002.

During the study period, mean, minimum and maximum water temperatures were measured respectively as 15.6, $4.0^{\circ} \mathrm{C}$ (in February 2002) and $25.0^{\circ} \mathrm{C}$ (June 2002) in Sarımsaklı Dam Lake. It was not able to do sampling in December and January because of freezing of surface of the lake (Figure 2).

Mean $\mathrm{pH}$ value of Sarımsaklı Dam Lake was 8.43 and minimum and maximum $\mathrm{pH}$ values were determined respectively as 7.0 (in September 2001 at $2^{\text {nd }}$ station) and 9.3 (in November 2001 at $2^{\text {nd }}$ station) (Figure 2).

For the study period, mean, maximum and minimum electrical conductivity (EC) of Sarımsaklı Dam Lake were found respectively as $442.5 \mu \mathrm{S} / \mathrm{cm}, 520.0 \mu \mathrm{S} / \mathrm{cm}$ and $400.0 \mu \mathrm{S} / \mathrm{cm}$ (Figure 2).

Mean Secchi depth was found to be $1.18 \mathrm{~m}$ in Sarımsaklı Dam Lake. Water clarity showed variation both depending on seasonal conditions and among stations. Maximum and minimum Secchi depths were measured respectively as $3.5 \mathrm{~m}$ in May 2002 at $1^{\text {st }}$ station and 0.45 $\mathrm{m}$ in November 2001 at $3^{\text {rd }}$ station (Figure 2).

Mean, minimum and maximum dissolved oxygen concentrations were measured respectively as $9.01,5.6 \mathrm{mg} / \mathrm{l}$ (in May 2001 at $2^{\text {nd }}$ station) and $13 \mathrm{mg} / \mathrm{l}$ (in June 2001 at $2^{\text {nd }}$ station) in Sarımsaklı Dam Lake (Figure 2). 

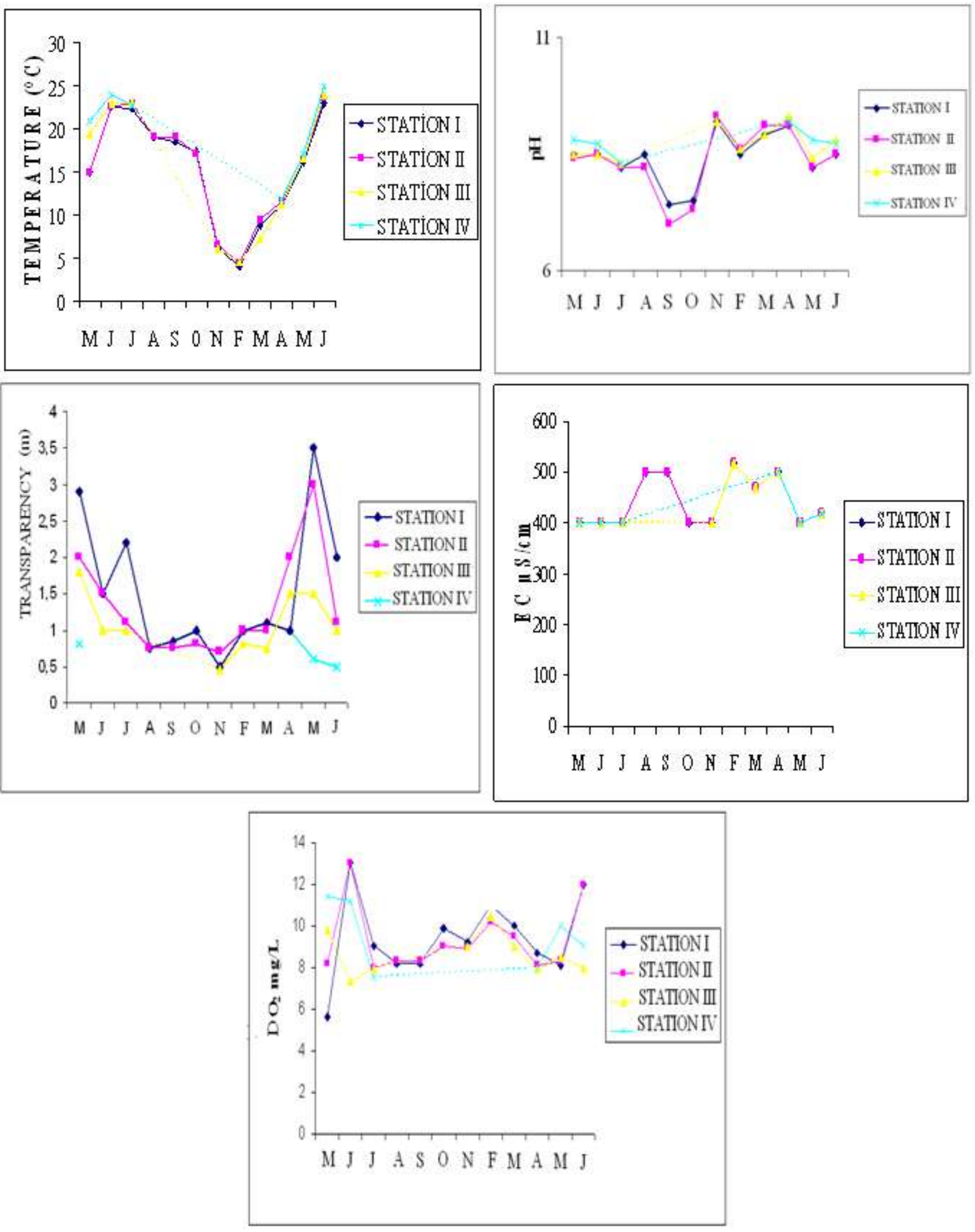
Figure 2. Monthly change of average value in some physico-chemical parameters of Sarımsaklı Dam Lake in 2001 - 2002. 
Table 1. Analysing result for Sarımsaklı Dam Lake.

\begin{tabular}{|c|c|c|c|c|c|c|c|c|c|c|c|c|c|}
\hline \multirow{2}{*}{\multicolumn{2}{|c|}{ Parameters }} & \multicolumn{4}{|c|}{ Station I } & \multicolumn{4}{|c|}{ Station II } & \multicolumn{4}{|c|}{ Station III } \\
\hline & & Spr. & Sum. & Fall & Win. & Spr & Sum & Fall & Win & Spr & Sum & Fall & Win \\
\hline $\mathrm{pH}$ & & 7.90 & 8.25 & 7.45 & 8.01 & 8.19 & 7.85 & 8.00 & 7.85 & 8.43 & 8.06 & 7.75 & 7.91 \\
\hline Chemical oxygen demand (COD) & $\mathrm{mg} / \mathrm{l}$ & 17 & 34 & 18.00 & 68 & 27 & 31 & 25 & 64 & 27 & 31 & 24 & 90 \\
\hline Surface active substance & $\mathrm{mg} / \mathrm{l}$ & 0.36 & 0.94 & 0.28 & 0.07 & 0.16 & 0.19 & 0.14 & $<0.05$ & 1.46 & 0.49 & 0.33 & 0.11 \\
\hline Sulphur & $\mathrm{mg} / \mathrm{l}$ & 0.05 & 0.04 & 0.05 & 0.05 & 0.03 & 0.04 & 0.03 & 0.03 & 0.05 & 0.04 & 0.05 & 0.05 \\
\hline Nitrate & $\mathrm{mg} / \mathrm{l}$ & 1.71 & $<0.05$ & 0.04 & 0.5 & 1.63 & $<0.5$ & 0.05 & $<0.1$ & 1.65 & $<0.1$ & 0.05 & 1.7 \\
\hline Nitrite & $\mathrm{mg} / \mathrm{l}$ & 0.068 & 0.04 & 1.72 & 0.05 & 0.06 & 0.03 & 1.64 & 0.04 & 0.005 & 0.03 & 1.69 & 0.05 \\
\hline Total phosphate & $\mathrm{mg} / \mathrm{l}$ & $<0.05$ & $<0.5$ & $<0.4$ & $<0.05$ & $<0.05$ & $<0.5$ & $<0.4$ & $<0.05$ & $<0.05$ & $<0.5$ & $<0.4$ & $<0.05$ \\
\hline Phosphate & $\mathrm{mg} / \mathrm{l}$ & 0.1 & $<0.3$ & $<0.2$ & 0.2 & 0.2 & $<0.3$ & $<0.1$ & 0.3 & 0.1 & $<0.3$ & $<0.1$ & 0.3 \\
\hline Oxygen saturation & $\mathrm{mg} / \mathrm{l}$ & 57 & 17.1 & 14 & 4.5 & 65 & 16.0 & 17 & 6.7 & 60 & 16.6 & 13 & 6.5 \\
\hline
\end{tabular}

Mean oxygen saturation level throughout the year was $37.75 \%$ and minimum and maximum values were found respectively as $4.5 \%$ (in winter period at $1^{\text {st }}$ station) and $65 \%$ (in spring period at $2^{\text {nd }}$ station). Mean, minimum and maximum values of COD were found respectively as 53.5, 17 and $90 \mathrm{mg} / \mathrm{l}$ (Table 1).

Some nutrients (nitrite, nitrate, sulphur, total nitrogen, phosphate, total phosphorous) and some other variables (such as COD, surfactant and suspended solid matter) were seasonally investigated in Sarımsaklı Dam Lake (Table 1).

During the study between May 2001 and June 2002 , a total of 45 species were determined. Of these species, $57 \%$ was Rotifers, $21 \%$ was Cladocerans and $22 \%$ was Copepods. It was determined that Rotifers was predominant in terms of both number of species and density $\left(\mathrm{BS} / \mathrm{m}^{3}\right)$ (Table 2).

Water regime has frequently changed in the dam lake due to irrigation, the lake is shallow and no stratification was determined between surface and deep waters. Even in months that minimum temperatures were found, Rotifers were predomi- nant in the lake in terms of species diversity and density. This may show that Rotifer group includes species with a high tolerance against variable temperatures.

Minimum dissolved oxygen level of water should not be below $5.0 \mathrm{mg} / \mathrm{l}$ to sustain the aquatic life under aerobic conditions in freshwater ecosystems (Gülle, 1999). This value was not found to be a limiting factor for life in Sarımsaklı Dam Lake.

Mean $\mathrm{pH}$ value of Sarımsaklı Dam Lake was measured as 8.43 and $\mathrm{pH}$ varied between 7.0 and 9.3. According to Turkish Environmental Regulation, a pH value between 6.5 and 8.5 should be obtained if lake, pond and dam lake reservoirs are natural protection area or for recrea-tional usage (Tanyolac, 2000).

It is known that high EC values are a good indicator of eutrophic waters (Radwan, 1984). Mean, maximum and minimum EC values of Sarımsaklı Dam Lake were measured respecttively as $442.5,520.0$ and $400.0 \mu \mathrm{s} / \mathrm{cm}$. Since there was no stratification within the lake, an important difference among EC values was not observed during the study period.
Secchi depth is one of the values using as an indicator of trophic state of a lake, as well. According to their trophic states and based on OECD limit values, lakes were classified as eutrophic (0.8-1.5 m), mezotrophic (1.4-2.4 m) and oligotrophic (3.6-5.9) (Ryding and Rast, 1989). Mean Secchi depth was found as $1.18 \mathrm{~m}$ in Sarımsaklı Dam Lake. Minimum and maximum values were measured respectively as $0.45 \mathrm{~m}$ (in November 2001 at $3^{\text {rd }}$ station) and 3.5 (in May 2001 at $1^{\text {st }}$ station). According to the classification above, Sarımsaklı Dam Lake is a lake with eutrophic character.

The results of the present study show that Sarımsaklı Dam Lake is an eutrophic lake in terms of water quality parameters and zooplankton species. This shows that the trophic state of the dam lake has been changed to an eutrophic state. The main reason of this is that the high amount of pollutants has entered into the dam lake. Therefore, it is immediately needed to get some measures for conservation of water quality of the dam lake. The zooplankton species detected in Sarımsaklı Dam Lake are new records since there 
Table 2. Temporal distribution of most abundant Rotifera, Cladocera and Copepoda species in Sarımsaklı Dam Lake between in May 2001 and June 2002.

\begin{tabular}{|c|c|c|c|c|c|c|c|c|c|c|c|c|}
\hline \multirow{2}{*}{ Species } & \multicolumn{7}{|c|}{2001} & \multicolumn{5}{|c|}{2002} \\
\hline & M & $\mathbf{J}$ & $\mathbf{J}$ & A & $\mathbf{s}$ & 0 & $\mathbf{N}$ & $\mathbf{F}$ & M & $\mathbf{A}$ & M & $\mathbf{J}$ \\
\hline \multicolumn{13}{|l|}{ Rotifera } \\
\hline Synchaeta littoralis & + & - & - & - & - & - & - & + & + & - & - & - \\
\hline Synchaeta oblonga & - & + & - & - & - & - & - & - & - & - & - & + \\
\hline Synchaeta pectinata & - & - & - & - & + & - & - & - & + & - & + & - \\
\hline Polyarthra vulgaris & + & + & + & + & + & + & + & + & + & + & + & + \\
\hline Polyarthra dolichoptera & + & + & + & - & + & + & + & - & + & + & + & + \\
\hline Keratella quadrata & + & + & + & - & + & + & + & + & + & + & + & + \\
\hline Keratella cochlearis & - & - & - & - & + & + & + & + & + & + & - & - \\
\hline Testudinella mucronata & + & - & - & - & - & + & - & - & - & - & + & - \\
\hline Testudinella patina & + & + & - & - & - & - & - & - & - & - & + & - \\
\hline Euchlanis dilatata & + & - & - & - & - & - & - & - & - & - & + & - \\
\hline Lecane closterocerca & + & - & - & - & - & - & - & - & - & - & - & - \\
\hline Lecane hamata & - & - & - & - & - & - & - & + & - & - & - & - \\
\hline Cephalodella catellina & + & - & - & - & - & - & - & - & - & - & - & - \\
\hline Cephalodella gibba & - & - & - & + & + & - & - & - & - & - & - & - \\
\hline Colurella adriatica & + & - & - & - & - & - & - & + & - & - & - & + \\
\hline Colurella uncinata & + & - & - & - & - & - & - & - & - & - & - & - \\
\hline Trichocerca stylata & - & + & - & + & + & - & - & - & - & - & - & + \\
\hline Trichocerca pusilla & - & - & - & - & + & - & - & - & - & - & - & - \\
\hline Trichocerca elongata & + & - & - & + & - & - & - & - & - & - & + & - \\
\hline Ascomorpha saltans & - & + & + & - & + & - & - & - & - & - & - & + \\
\hline Conochilus sp & - & + & + & - & - & - & - & - & - & - & - & + \\
\hline Hexarthra fennica & - & + & + & + & + & - & + & + & - & - & - & + \\
\hline Asplancha girodi & - & - & - & - & - & - & - & - & + & + & - & - \\
\hline Asplancha priodontha & - & + & + & + & + & - & - & - & + & + & - & + \\
\hline Asplancha sieboldi & - & + & - & + & + & - & - & - & - & + & - & + \\
\hline Filinia terminalis & - & - & - & - & + & - & - & + & + & & - & - \\
\hline Filinia longiseta & - & - & - & + & + & - & - & + & + & + & - & - \\
\hline Lepadella ovalis & - & - & - & - & - & - & - & + & - & - & - & - \\
\hline Notholca squamula & - & - & - & - & - & - & - & - & + & - & - & - \\
\hline Notholca aqumunata & - & - & - & - & - & - & - & - & + & + & - & - \\
\hline Monommata s. & - & + & - & - & - & + & + & - & - & - & - & - \\
\hline Rotaria rotatoria & - & - & - & - & - & - & - & - & + & - & - & - \\
\hline Philodina megalotrocha & - & - & - & - & - & - & - & - & + & - & - & - \\
\hline \multicolumn{13}{|l|}{ Cladocera } \\
\hline Diaphanosoma brachyurum & - & + & + & + & + & - & - & - & - & - & - & + \\
\hline Daphnia magna & + & + & + & - & - & + & - & - & - & - & + & - \\
\hline Daphnia longispina & + & + & + & + & - & + & + & + & + & + & + & + \\
\hline Daphnia pulex & + & + & - & - & - & + & + & - & - & + & + & + \\
\hline Ceriodaphnia quadrangula & + & + & + & + & + & - & - & - & - & - & - & + \\
\hline Macrothrix laticornis & + & - & - & - & - & - & - & - & - & - & - & - \\
\hline Bosmina longirostris & + & + & + & + & + & + & + & + & + & + & + & - \\
\hline Disparalona rostrata & + & + & - & - & - & - & - & - & - & - & + & - \\
\hline Cydorus sphaericus & + & - & - & + & + & - & - & - & - & + & + & - \\
\hline Alona guttata & + & - & - & - & - & - & - & - & - & - & - & - \\
\hline \multicolumn{13}{|l|}{ Copepoda } \\
\hline Cyclops vicinus & + & + & + & + & + & + & + & + & + & + & + & + \\
\hline $\begin{array}{l}\text { Acanthadiaptomus } \\
\text { denticornis }\end{array}$ & + & + & + & + & + & + & + & - & - & - & - & - \\
\hline
\end{tabular}


is no previous study regarding this subject in the lake.

\section{REFERENCES}

Dussart B (1967). Les Copépodes des eaux continentales D' Europa Occidentale Tome: I Calanoides et Harpacticoides, Editions N. Boubee' and cie, 500p, Paris.

Edmondson WT (1959). Rotifera in freshwater biology. Second edition, John Wiley and sons inc. New York, pp. 420-494.

Gülle I (1999). Kovada Gölü zooplanktonunun sistematik ve ekolojik yönden araştırılması. Yüksek lisans tezi, Süleyman Demirel Üniversitesi, Eğirdir.

Harding JP, Smith WA (1974). A key to the British Freshwater Cyclopoid an Calanoid Copepods. 2. edition. Freshwater Biol. Ass. Sci. Publ., no 18, U.K.
Kolisko RA (1974). Plankton rotifers biology and taxonomy biological station lunz of the Austrian Academy of science, Stuttgart.

Koste W (1978). Die Radertiere Mittelevrapas I. Textband. Berlin, Stuttgart, p. 670.

Needham JG (1962). A guide to the study of freshwater biology. 5 . Edition, Holden Day Inc., San Francisco.

Ryding, SO, Rast W (1989). The Control of Eutrophication of Lakes and Reservoirs. Man and the Biosphere Series Volume I. The Parthenon Publishing Group. pp. 1-314.

Radwan S (1984). The Influence of some abiotic factors on the rotifers of Teczna and Wtodowa Lake District. Hydrobiologia, 112: 117-124.

Tanyolac J (2000). Limnoloji, Hatipoğlu Yayınevi, 263s., Ankara.

Ward B, Whipple GC (1945). Freshwater biology, second edition, John Wiley and Sons inc. New York. 